\title{
TEACHING WRITING RECOUNT TEXT BY USING SCRAPBOOK THROUGH PROJECT BASED LEARNING IN THE EIGHT GRADE OF SMP NEGERI 8 KEDIRI
}

\author{
Intan Yuritanti Agustina
}

\begin{abstract}
This research was carried out to answer about the preparation, implementation, students' response, and students' writing in teaching writing recount text by using scrapbook through project-based learning since corona virus pandemic. The design was descriptive qualitative. The data collecting method were interview, observation, questionnaire and documentation. The result of this research showed that the preparation had been supported by the sets of equipment such as by syllabus, lesson plan, learning model, technique, material, media, and assessment. Then, the implementation was implemented in six steps. Then, the students' responses showed in percentage 92\%. It meant that the students gave the positive responses. While, the students' written showed that all the students has completed $100 \%$ the writing task. All the students' value above minimum criteria of mastery learning. From the result finding, it showed that teaching writing by using scrapbook through project-based learning was good to improve students' writing ability.
\end{abstract}

Keywords: project-based learning, scrapbook, writing

\section{INTRODUCTION}

Writing skills become one of the skills in English that has a very significant effect nowadays. People use it not only in verbal communication to communicate with one another, but also non-verbal communication. The implication, writing is a necessary variety of communication and it's used as a method of communication to connect people in a different time and place. A good writing skill makes the students able to convey their thoughts and communicates their ideas. Based on Suparno in Triambodo (2015) said that writing is an activity of delivering the message as the communication by using written language.

Furthermore, based on the observation in the eighth grades of SMP Negeri 8 Kediri, the researcher found that the students have more interest and motivation in writing, whereas usually students do not like learning related to writing. This happened because learning is carried out by an interesting teacher. Interesting learning will encourage students to be active in learning. They were be bored with the learning, as has been done by one of the English teachers in SMP Negeri 8 Kediri. English teacher used scrapbook as a medium for student writing. Students to be more active and creative using this media, they also have the motivation to take lessons in every meeting. They feel that the new atmosphere will be more interesting, and this was done in SMP Negeri 8 Kediri especially in eight grade by 
using scrapbook. Writing skill is much more fun and colorful than just using white paper, because in the 2013 curriculum not only knowledge but also encompass students' skills and creativity. So, the scrapbook is very helpful in the learning process especially writing.

The scrapbook is one of the visual media which makes the students easier in getting the material in learning (Wahyu, 2015). By using Scrapbook, the students can tell their past story in a beautiful and interesting look. The scrapbook as media, can be used for the students to share their experience or story in the past through collecting of memorabilia, poetry, quotes, photos, clippings, and others, compiled and arranged in an album or handmade book (Astuti, 2013). The scrapbook is different with picture and picture media, in the picture and picture media the students only can listen and see what explained by the teacher through the picture that has stuck on the paper, while scrapbook involves the students directly in the process of learning (Indah, 2017). While, the model of learning used Project based learning model.

As Bell (2010) said, project based learning is a successful innovative approach to learning that teaches a multitude of strategies for success in the twentyfirst century. Project based learning also challenges students to gain their skills in writing. Project-based learning is one of the learning models that can be used to make students feel motivated and attract attention in writing. This model has the potential to be very challenging and motivate students because this learning model provides a very interesting result. There were seven steps to do the model. Those were starting with essential questions, designing a plan for the project, creating a schedule, monitoring the students and the progress of the project, assessing the outcome, and evaluating the experience (Kemdikbud, 2014)

Dealing with the explanation above, the researcher wants to investigate the teaching writing recount text by using scrapbook through project based learning. This research focused on the preparation, implementation, students' responses and students' writing task in the teaching writing recount text by using scrapbook through project based learning in the eight grade of SMP Negeri 8 Kediri.

\section{RESEARCH METHOD}

This research used a descriptive qualitative study. According to Saifuddin (2013), descriptive study, which is analyzing and presenting facts systematically so that it is easily understood and concluded. The conclusions produced were basic factually. Conclusions were based on numbers processed not too deep and based on percentage analysis. The data source selected the English teacher, assisstant principal of academic affairs and curriculum, and the students in the eight of SMP Negeri 8 Kediri. The instruments which were needed in this study were observation checklist, students' writing task, and questionnaire.

The researcher collected the data by conducting the interview, observation, questionnaire and documents. The interview was to know the preparation of teaching. While the observation was to know the implementation in the first meeting. Because of the COVID-19 virus, the observation continued by analyzing the lesson plan. Then, the students' responses got from the questionnaire. Continuing collected some documents like lesson plan, syllabus, pictures, etc. By 
using descriptive qualitative research design the description evolved naturally and it can help to describe the whole real condition and situation of the object of research (Moleong, 2011).

\section{FINDING AND DISCUSSION Finding}

The data was about the findings related to the focus of research, they were: the preparation, implementation, students' responses, and students' writing task toward the teaching writing recount text by using scrapbook through project based learning

\section{The Preparation}

\section{According to the Teacher}

1. Syllabus

Based on the result finding, syllabus was the important equipment for teaching because syllabus was the guide in teaching. So, before the teacher taught in the class, she should made the syllabus. According to the teacher, syllabus was a set of plans and arrangements for implementing learning and assessment that are systematically compiled that contain components that are interrelated to achieve mastery of basic competencies. From the interview data result about syllabus, the teacher always made the syllabus in every meeting. For making the syllabus did not need much time because she has used a form from BNSP/Ministry of education and culture. The teacher only developed the syllabus according to the material used.

\section{Lesson Plan}

Based on the research finding lesson plan was as important as syllabus. From the interview result with the English teacher, she said that she used matrix form to make the lesson plan. The form of lesson plan consisted of school identity, subject identity, class/semester, subject matter, time allocation, learning objectives, basic competencies and indicators, learning material, learning media, learning resources, learning steps, and assessment. The English teacher said that she used the form from ministry of education and culture and the content of lesson plan developed by the teacher as creative as possible according to the material used.

\section{Learning Model}

According to the interview with the English teacher, she used project based learning model to reach the goal in curriculum 2013 scientific approach. She has used the model for about 3 years and every year there were the evaluation of the teaching by using project based learning. There were six steps to teach by using project based learning method. Those were starting with the essential questions, designing a plan for the project, creating a schedule, monitoring the students and the progress of the project, assessing the outcome, and evaluating the experience. By using learning model of project based learning, the students were enthusiastic. 
4. Technique

In teaching learning model, the teacher applied techniques that support the teaching learning model (project based learning). According to the interview result, to achieve the goal of teaching writing recount text by using scrapbook, the English teacher used video call to complete one of the steps of project of learning that is monitoring for the students project. It can help the students in their home when there is covid-19 virus nowadays. According to the teacher about technique, to choose the technique depended on the students, and the condition in the class. And she used the video call to use Project based learning and it is very effective.

\section{Material}

Based on the research finding, material was the important things in teaching. Without material the teacher did not know what the students achieve in learning. According to the interview, the English teacher used recount text as the material. The recount text was about personal recount. So, the students should tell their personal experience. The teacher should be creative in arranging the material. To teach about recount text, the teacher said that the students should know about language features and generic structure of recount text. Then, the source got from the internet and teacher's book from government.

\section{Media}

As the interview result, the teacher said that the function of the media was to support the learning in the class. The good media can bring fun learning in the class. By using the media, the teacher hoped that the students understood well about the material. According to the interview, the media used scrapbook. Because the teacher used project based learning and the students should produce the product. So, the teacher used the scrapbook as the main media. Other media used PPT and Video. They were used when learning in the class

\section{Assessment}

From the interview with the English teacher, the teacher used the rubric assessment in the teacher's book from government. The assessment include knowledge, attitude, and skill. The attitude can be got from the observation when they were in the class and consult with the teacher, knowledge can be got in the class when the student answered and did the questions given, and the skill is from the writing recount text in the scrapbook. Before, the teacher gave the value to the students, she told the students about the assessment criteria. So, the students prepared well to get the good value. Then, the minimum criteria of mastery learning in the SMP Negeri 8 Kediri was 75.

\section{According to the Aassistant Principal of academic affairs and curriculum}

The teaching had supported well by the sets of equipment in the learning process as like syllabus, lesson plan, learning model, technique, material, media, and the way to assesst. The teacher always prepared the equipment of learning well 
before taught in the class. The teacher used the guide from the minister of education and culture when she made the preparation.

\section{The Implementation}

Teaching class by using scrapbook through project based learning was done in 3 meetings. It held in the eighth grade of SMP Negeri 8 Kediri. The class was using excel class, especially the A-class. There are 32 students in A-class. The resulting finding of implementation as below:

\section{The First Meeting}

The first meeting was done on Wednesday, $11^{\text {th }}$ of March 2020. The class was started at 7.00 a.m. and ended at 8.20 a.m. The total of students was 32 in the first meeting. The observation result as follows:

\section{Pre Activities}

Before the class began, the students had come to the class. The teacher greeted the students before class started and prayed together. After that, the teacher checked the attendance list of the students, continued by giving a spirit to the student, which was yel-yel. The yel-yel was "English, Easy, Bahasa, I love it". After that, the teacher gave the information about the goal of learning.

\section{Starting with Essential Questions}

The teacher gave a short conversation according to the material. Giving the questions to the students about the material that was recount text. Next, the teacher asked the students to open their book in chapter 10. That is about recount text matter. The teacher asked the students about the meaning of the title, the students directly answered it. Then, the teacher asked the students to read the material about recount text and about the goal that they learnt in recount text, those were trying to share our experience, to show that, to learn from the events/experience, to report them. After that, the teacher pleased the students to ask her about the things that the students did not know. But, no one asked the question, meant they have known the material. Then, the teacher showed the video that had been prepared about recount text. The students paid attention to the video player. The video consisted of definition, purpose, generic structure, and language features of recount text. After knowing about recount text, the teacher asked the students to find detailed information about the text. Its about the generic structure and the language features used. The students looked understood well about the generic structure and language feature of recount text. Next, because the students have understood the material, the teacher gave information about the project that the students made. The students made the "diary". The teacher pleased the students to ask what the teacher meant about making a diary. Then, the teacher said that the student should make the diary by themselves by using recycle used, then made them in the scrapbook.

\section{Designing the plan of the project}

The teacher asked the students to make a draft of their project. The draft was about the preparation to make them. The draft consisted of the goal to make the 
project, result of the project that will the students made, activities (how to finish the project), finishing (just submit or another way to finish), the instrument used to make the project form recycle used, strategy to do all preparation. While the students made the plan, the teacher monitored the students to do the draft. The teacher checked the work from the students. If the students still confused, the teacher explained again. After all the students have finished doing their work, the teacher asked two to three students to read their work. And the teacher corrected the students' work. After all of finished, the teacher reviewed the material that has been learned that day and prepared for the next lesson to be learned in the class. Then the teacher closed the class.

\section{The Second Meeting}

The second meeting that the estimated research was held on Wednesday, 18 March 2020 should be stopped because of the corona virus (COVID-19). The school was closed. The learning was done at home by online learning. The online learning by using Whatsapp application. So, the researcher got the data of the second meeting was from the lesson plan made by the teacher. The researcher analyzed the lesson plan. When the researcher did not understand about the point of lesson plan, the researcher asked the teacher. The implementation as follows:

\section{Creating A Scheduled Stage}

In this stage, the teacher divided some groups. One group consisted of four to six students. The groups were made for consulting the project. So, with their group, the students consulted together. Then, the student made the schedule for consulting and submitting the project. All the students made agreement about the schedule because the schedule must be agreed by all the students. After making the schedule, the teacher asked the students to continue their writing and scrapbook about their diary.

\section{Monitoring The Students and The Progress of The Project.}

This step was done out of the time of teaching in the class. The students were doing the consultation as the schedule that have been stated. The teacher always monitored the work of project from the students by asking in the group of Whatsapp. The teacher asked the students to send some photos when they were doing their project in home. Then, the consultation by using video call Whatsapp with the group that have been made. The teacher always reminded the student to be discipline in doing consultation, so their project done in the right time and the result was good. The teacher gave the correction to the project of the students, then the students corrected again and doing consultation till the project was done.

\section{The Third Meeting}

The third meeting that the estimate research was held on Wednesday, 25 March 2020 in the class but the researcher got the data from the analysing of lesson plan. The implementation as follows: 


\section{Assessing the outcome and evaluating the experience}

In assessing the outcome, the student published their result project in group of Whatsapp. The time to publish the project followed to the schedule that the students made before. In this stage, the teacher also asked the students to show the project to the students' parents, and giving the comment in the paper that the teacher gave. After that, the teacher and students reflect on the project that have done by using Whatsapp application. At this stage, the teacher needed to make sure that the students are able to find the answer of essential question. The teacher and students shared their experience of conducting the project and discuss about the projects, what needed to change and improve for the following project, as well as share ideas on the new projects.

\section{The Students' Responses}

To know about students' responses about teaching writing recount text by using scrapbook through project based learning, the researcher used questionnaire. There were three indicators in the questionnaire. The indicators were implementation, difficulties and advantages. There were 42 questions to know the responses. The questions about implementation were 15, then 13 questions for difficulties, and 14 questions for advantages. There were two option in the questionnaire, that was "Yes" and "No". Every questions related to the students learning. The researcher done research in the eighth grade, exactly in A-class. Aclass is the excel class in that school. There are 32 students in that class but only 23 students done the questionnaire. The researcher done collecting the data of questionnaire by giving the questionnaire in the class group of Whatsapp. That was done because of covid-19 virus, we should do social distancing. The result of students' responses can be seen in table below:

Table 1. The result finding of students' responses on the implementation

\begin{tabular}{ll}
\hline & Implementation \\
\hline Questions & 15 \\
\hline Percentages & $97 \%$ \\
\hline
\end{tabular}

From the table above, the students' response to the implementation indicator was $97 \%$. Then the students' response of the difficulties indicator was below:

Table 2. The result finding of students' responses on the difficulties

\begin{tabular}{ll}
\hline & Difficulties \\
\hline Questions & 13 \\
\hline Percentages & $88 \%$ \\
\hline
\end{tabular}

From the table above, the students' response to the difficulties indicator was $88 \%$. Then the students' response of the advantage indicator was below: 
Table 3. The result finding of students' responses on the advantages

\begin{tabular}{ll}
\hline & Advantages \\
\hline Questions & 14 \\
\hline Percentages & $90 \%$ \\
\hline
\end{tabular}

From the table above, the students' response to the implementation indicator was $90 \%$.

\section{The Students' Writing Task}

Students' writing task result was to gain writing task toward the implementation of project based learning by using scrapbook in teaching writing recount text. That was one of the focus in this research. For giving the value the teacher used assessment rubric from ministry of education and culture. The skill components of writing that the teacher analysed were authenticity, content, organization, vocabulary, and language use.

The students' values were got from the teacher's documentation. The finding result of students' writing task shown that the highest score that the students got were 95 . While, the lowest score was 88 . The students who got the score of 88 was 13 students. Then, the students who got the score of 90 was 15 students. After that, the students who got the score of 93 was 3 students. And the students who got the score of 95 was 1 student.

But according to the documentation of rubric assessment in lesson plan. The result of writing task did not relate to the rubric assessment that the teacher had prepare. According to the rubric assessment the score of result got from the score that the student got divided to the maximum score from 5 indicator, that's 25 . After that times 100 . If the students writing was good, the students got 25 . It meant they got 100 score. Then, if they got 24. It meant, they got 96 score. While, if they got 23 , it meant they got 92 score. And then 22 meant they got 88 score. But according to the documentation value that the teacher gave, the score of the students were 88 , 90,93 , and 95 . Then, only score of 88 that related to the score of rubric assessment.

\section{Discussion}

According to the finding research that the researcher got, the teaching writing recount text by using scrapbook through project based learning had been supported by the sets of equipment in the learning process, such as syllabus, lesson plan, learning model, technique, media, material and assessment. For the syllabus, the form of syllabus used from BNSP (2006), it started from making competency standards till the source of learning. Then, the lesson plan form used matric form and it used the reference from the Ministry of Education and Culture (2016). And then, the learning model used project based learning. The model of learning has stated in the Minister of Education and Culture (2014). After that, technique used video call. Then, the material used recount text, especially about personal recount, personal recount text that shows the personally experience of the writer Rojas (2010). Next, media used scrapbook. While, the assessment included knowledge, attitude, and skill. And the assisstant principal of academic affairs and curriculum 
said that before the teacher taught in the class, the English teacher always prepared the equipment.

The researcher did the observation of the teaching writing recount text by using scrapbook through project based learning in three meetings. From the three meetings, the teacher reached the goal of teaching. The teacher applicated the implementation of teaching writing recount text by using scrapbook through project based learning in six step. Those were starting with the essential questions, designing a plan for a project, creating a schedule, monitoring the students and the progress of the project, assessing the outcome, and evaluating the experience (Ministry of Education and culture, 2014). Based on the finding that the students can write something that indicate mastery on the elements of a new language (Rachmayanti in Riza 2016).

From the result of students' responses, the students' responses were 97\%, it meant that the students had followed the implementation step by step. While the difficulties showed $88 \%$, meant that the students did not face any difficulties in learning. Then, the advantages were $90 \%$, it meant that the students got advantages in the implementation of teaching writing recount text by using scrapbook through project based learning. Abidin (2007) the advantages of project based learning are the students involved in the learning process, there are collaborative learning and increase creativity. So, the conclusion showed that the students' responses was good because it showed $92 \%$ from three indicators.

From the analysis of students' writing, the highest score that the students got were 95 . While, the lowest score was 88 . The students who got the score of 88 was 13 students. Then, the students who got the score of 90 was 15 students. After that, the students who got the score of 93 was 3 students. And the students who got the score of 95 was 1 student. It meant all the students' value were above minimum criteria of mastery learning that's 75 . But according to the documentation value, the students score were good because they can passed the minimum criteria of mastery learning. And all of the students $100 \%$ completed the writing task of recount text. Therefore writing is one of skill that makes sense that the more they practice to write the better their writing (Langan, 2011).

\section{CONCLUSION \\ Conclusion}

Based on the result of the research, the preparation of teaching writing recount text by using scrapbook through project based learning had been supported by the sets of equipment in learning such as syllabus, lesson plan, learning model, technique, media, material and assessment. Then, the implementation of teaching writing recount text by using scrapbook through project based learning was implemented in six steps. The six steps were about starting with essential questions, designing a plan for a project, creating a schedule, monitoring the students and the progress of the project, assessing the outcome, and evaluating the experience. And then, the students' response toward the teaching writing recount text by using scrapbook through project based learning showed in percentage $92 \%$. The indicator of students' responses divided by three. The indicators included the implementation, difficulties and advantages. Then, it can be showed that the 
implementation responses were $97 \%$, it meant that the students had followed the implementation step by step. Then, the difficulties responses were $88 \%$, it meant that the students did not face any difficulties. While, the advantages responses were $90 \%$, it meant that the students got the advantages of the learning. So, all the students gave the positive responses. While, the students' written task toward the teaching writing recount text by using scrapbook through project based learning showed that all the students has completed 100\% the writing task. All the students' value above minimum criteria of mastery learning. That was above 75 .

\section{REFERENCES}

Abidin. (2014). Desain Sistem Pembelajaran dalam Konteks Kurikulum 2013. Bandung: Refika Aditama.

Avenue, T. (2013). Scrapbook Project. Canada: Canada Sasktchewan.

Bell, S. (2010). Project Based Learning for 21th Century: Skills for the Future. Taylor\&Francis Group, LLC.

BNSP. (2006). Panduan Penyusunan Kurikulum Tingkat Satuan Pendidikan Jenjang Pendidikan Dasar dan Menengah. Jakarta: Badan Nasional Standar Pendidikan.

Indah, N. (2017). The Relationship Between Using Scrapbook Media And Motivation in Learning Geography of Seventh Grade Students in SMP Negeri 41 Palembang. Edutech, 16 (3).

Kementerian Pendidikan dan Kebudayaan. (2014). Modul Pelatihan Implementasi Kurikulum 2013. Jakarta: Badan Pengembangan Sumberdaya Manusia Pendidikan dan Kebudayaan dan Penjaminan Mutu Pendidikan

Kementerian Pendidikan dan Kebudayaan. (2016). Modul Pelatihan Implementasi Kurikulum 2013. Jakarta: Badan Pengembangan Sumberdaya Manusia Pendidikan dan Kebudayaan dan Penjaminan Mutu Pendidikan

Langan, J. (2011). College Writing Skills with Reading-International Edition $8^{\text {th }}$ Edition. New York: McGraw-Hill,Inc.

Moleong, L.J. (2016). Metodologi Penelitian Kualitatif Edisi Revisi. Bandung: PT. Remaja Rosdakarya.

Riza, M. (2016). Teaching Writing Descriptive Text By Using Wall Magazine Through Project Based Learning For Students in The Tenth Graders of Sma Negeri 1 Jombang. Journal of Education. 04 (02), 71 - 80.

Rojas, V. (2010). Language Features of Seven Writing Genres. Crawley: Language Consultant.

Saifuddin, A. (2013). Metode Penelitian. Yogyakarta: Pustaka Pelajar.

Triambodo, G. (2015). Peningkatan Kemampuan Menulis Karangan Deskripsi Melalui Media Lingkungan dalam Pembelajaran Bahasa Indonesia. Jurnal Universitas PGRI Yogyakarta.

Wahyu, M. (2015). The Effectiveness of Scrapbook as A Media to Improve Students' Ability in Writing Recount Text "a Case of The Eighth Grade Students of SMP N 2 Gubug in the 2015 / 2016 Academic Year. Journal of Education. 6 (2). 